\title{
Üniversite Hastanesi Masa Başı Çalışanlarında Kardiyovasküler Hastalık Riski ve Fiziksel Aktivite Düzeyinin Cinsiyete Göre İncelenmesi
}

\section{Examination of the Risk of Cardiovascular Disease and Level of Physical Activity among Office Workers of the University Hospital with Regard to Gender}

\begin{abstract}
Mükerrem ERDOĞAN * Alpay GÜVENÇ **

Öz: Bu çalışmanın amacı, masa başı çalışanlarda kardiyovasküler hastalık riski ve fiziksel aktivite düzeyinin cinsiyete göre incelenmesidir. Araştırmaya üniversite hastanesinde masa başında çalışan toplam 401 kişi (128 erkek ve 273 kadın) katılmışırı. Kardiyovasküler hastalık riski, katılımcıların bel çevresi ve bel kalça oranı belirlenerek değerlendirilmiştir. Katılımcılara ilişkin fiziksel aktivite düzeyi "Uluslararası Fiziksel Aktivite Değerlendirme Anketi” kısa formu kullanılarak incelenmiş ve fiziksel aktivite düzeyi; "aktif olmayan", "dü̈sük" ve "yeterli" olarak sınıflandırılmıştır. Verilerin istatistiksel analizinde ki-kare testi kullanılmıştır. Masa başı işi yapan bireylerin \% 93,5'inin yetersiz fiziksel aktivite düzeyine sahip olduğu ve sadece \% 6,5'inin fiziksel aktivite düzeyinin yeterli olduğu belirlenmiştir. Erkek masa baş1 çalışanlarda fiziksel aktivite düzeyinin kadın çalışanlara göre anlamlı ölçüde yüksek olduğu bulunmuştur $(\mathrm{p}<0.05)$. Ancak fiziksel aktivite düzeyindeki bu cinsiyet farklılığı, "yeterli” düzeyde fiziksel aktivite değişkenliğinden değil, "aktif olmayan" ve "düşük" fiziksel aktivite düzeyi gruplarındaki değişkenlikten kaynaklanmaktadır. Diğer taraftan bel çevresi ve bel kalça oranı dağılımları dikkate alındığında, katılımcıların yarısından fazlası artmış ya da yüksek kardiyovasküler hastalık riski taşımamaktadır. Bununla birlikte fiziksel aktivite düzeyi, kardiyovasküler hastalık riski olarak kabul edilen bel çevresi ya da bel kalça oranı gruplarına göre değişkenlik sergilememektedir. Bu durum örneklemi oluşturan bireylerin fiziksel aktivite düzeyinin oldukça yetersiz olmasından kaynaklı olabilir.
\end{abstract}

Anahtar sözcükler: Kardiyovasküler Hastalık Riski, Fiziksel Aktivite, Ofis Çalışanları, Bel Kalça Oranı

Abstract: The aim of this study was to examine the risk of cardiovascular disease and the level of physical activity among office workers according to gender. The participants in this study consisted of 401 office workers (128 men and 273 women) at Akdeniz University Hospital. The waist circumference and waist-to-hip ratio were determined and used as the predictors of the risk of cardiovascular disease. The short form of "International Physical Activity Questionnaire" was used to determine the levels of physical activity of the participants. These levels were classified as "non-active", "low" and "sufficient". The data obtained was analyzed using the chi-square test. Statistical analysis showed $93.5 \%$ of the participants' physical activity levels were classified as "non-active" or "low" and only $6.5 \%$ of the workers displayed 'sufficient' activity level. The physical activity level of the male workers was significantly higher than the female workers $(\mathrm{p}<0.05)$, but this difference was related to differences between the "non-active" and the "low" activity groups. In terms of waist circumference and waist-to-hip ratio, more than half of the participants was not at a high risk of cardiovascular disease. The level of physical activity did not vary according to waist circumference or to waist-to-hip ratio groups, which were used as the predictors of the risk of cardiovascular disease. This may have been due to the low level of physical activity of the participants.

Keywords: Risk of Cardiovascular Disease, Physical Activity, Office Workers, Waist-to-Hip Ratio

\footnotetext{
* Öğr. Gör., Akdeniz Üniversitesi, Sağlık Hizmetleri Meslek YO., Antalya. mukerremerdogan@akdeniz.edu.tr

** Doç. Dr., Akdeniz Üniversitesi, Spor Bilimleri Fakültesi, Antenörlük Eğitimi Böl., Antalya. guvenc@akdeniz.edu.tr
} 
Kardiyovasküler hastalıklar genel anlamda kalp ve dolaşım sistemi rahatsızlıklarından oluşan kapsayıcı bir terimdir. Bu hastalıklar koroner kalp hastalıklarını, hipertansif hastalıkları, periferik arter ve serebrovasküler hastalıkları, inme ve ritim bozukluklarını kapsamaktadır. Kardiyovasküler hastalıklar tüm dünyada ve ülkemizde en önemli morbidite ve mortalite nedenidir (Yılmaz \& Boylu 2016; Balcı 2018). Dünya Sağl1k Örgütünün verilerine göre kardiyovasküler hastalıkların küresel ölüm nedenleri arasında birinci sırada yer aldığ 1 ve yılda 7,6 milyon kişinin bu hastalıklar nedeniyle yaşamını kaybettiği belirtilmektedir. Ayrıca kardiyovasküler hastalıkların Avrupa'daki 4,3 milyondan fazla ölümün doğrudan ve her yıl tüm ölümlerin yaklaşık olarak yarısının (\%48) nedeni olduğu bildirilmektedir (Petersen 2008). Ülkemizde de önemli bir sağlık sorunu olan kardiyovasküler hastalıklar erişkin ölüm nedenleri arasında ilk sırada yer almaktadır (Onat 2008). Türkiye İstatistik Kurumu 2016 yılı verilerine göre, Türkiye’de ölüm nedenleri incelediğinde en fazla \%39,8 ile kardiyovasküler hastalıkların ilk sırada yer aldığ 1 görülmektedir. Bu ölümlerin \%40,5’i iskemik kalp hastalığ1, \%23,6's1 ise serebrovasküler hastalıklardan kaynaklanmıştır.

Diğer taraftan kardiyovasküler hastalıklara, önlenemez ve önlenebilir risk faktörleri neden olmaktadır. Genetik yatkınlık, yaş ve cinsiyet önlenemez risk faktörleri iken, aşırı kilo, artmış bel çevresi ve bel kalça oranı, dislipidemi, diyabet, hipertansiyon, tütün ve alkol kullanımı, yan1ış beslenme, stres gibi psikolojik etkenler, hareketsiz yaşam ve fiziksel aktivite azlığı önlenebilir risk faktörlerindendir. Önlenebilir risk faktörlerinin varlığ kardiyovasküler hastalıkların gelişme riskini daha da artırabilmektedir (Y1lmaz \& Boylu 2016; Balc1 2018).

Bununla birlikte fiziksel aktivite, diğer önlenebilir risk faktörlerini de olumlu yönde etkileme potansiyeli olduğundan bu faktörler arasında öne çıkmaktadır. Hareketsiz bir yaşam tarzının kardiyovasküler hastalık riskini artırdığı, fiziksel olarak aktif bir yaşam tarzının ise, kolesterol düzeyini düşürme, kan basıncını dengeleme, vücut ağırlığını, yağ yüzdesini ve bel çevresini azaltma, fiziksel uygunluğu geliştirme gibi etkileriyle kardiyovasküler hastalık riskini azalttığı çeşitli araştırma sonuçlarında bildirilmektedir (Batty \& Lee 2004; Tsai 2004; LaMonte et al. 2005; Perry \& Bennett 2006; Haskell 2007; Petersen 2008; Hua 2009; Hamer 2012).

Günümüzde çalışma ortamı veya günlük hayatta fiziksel aktivite ile üretilen işlerin artık teknolojik araçlar kullanılarak yapılır hale gelmesi, insanların hareketsiz yaşam tarzına geçişinde baş rolü oynayan etken olmuştur. Çağımızın modern yaşam şekli, bilgisayar karşısında daha fazla hareketsiz zaman geçirme ve iş yerlerinde teknoloji kullanımı işlerin daha az fiziksel aktivite ve enerji harcanarak yürütülmesini ve bedenin kullanamadığı enerjiyi yağ olarak biriktirmesini beraberinde getirmektedir (Özer \& Baltacı 2008). Bu da başta obezite ve buna bağlı değişkenler olmak üzere birçok önlenebilir kardiyovasküler hastalık riskini tetikleyebilir.

Özellikle çalışma hayatında masa başı işi yapan kişiler de mesleki gereksinimden dolayı daha az hareket ettikleri ve uzun süre hareketsiz kalabildikleri için kardiyovasküler hastalıklar için riskli grupta yer alabilirler. Risk gruplarının belirlenmesi ile hastalıklar konusunda birey ve toplumun farkındalığını artırma, önleyici tedbirler alma ve yaşam tarzı değişikliklerini teşvik etme sağlanabilir. Bu nedenle masa başı işlerde çalışan bireylerin kardiyovasküler hastalık riskinin ve fiziksel aktivite düzeyinin incelenmesi oldukça önemlidir.

Buradan hareketle bu araştırmada masa başı çalışanlarda kardiyovasküler hastalık riski ve fiziksel aktivite düzeyinin cinsiyete göre değerlendirilmesi amaçlanmıştır.

\section{Yöntem}

\section{Katılımcilar}

$\mathrm{Bu}$ araştırmaya Antalya ilinde ikamet eden ve Tıp Fakültesi Hastanesinde günlük sekiz saat me- 
sai süresince görevini masa başında oturarak ve bilgisayar kullanarak yapan toplam 454 kişiden 401’i gönüllü olarak katılmıştır. Dolayısı ile bu çalışmadaki katılımcılar araştırma evreninin \%88,33'ünü temsil etmektedir. Bu çalışmaya katılan ve işleri gereği masa başında iş üreten toplam 401 hastane çalışanından 273'ü kadın, 128'i ise erkektir. Kadın $(n=273)$ ve erkek $(n=128)$

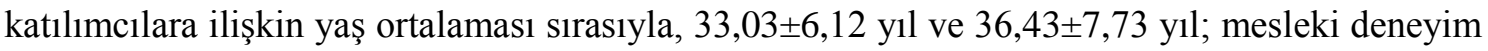

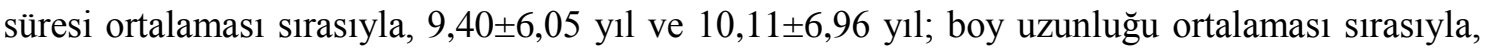
$162,37 \pm 5,47 \mathrm{~cm}$ ve $174,78 \pm 6,35 \mathrm{~cm}$ ve vücut ağırlığ ortalaması ise sirasıyla, $62,83 \pm 10,48 \mathrm{~kg}$ ve $80,37 \pm 10,66 \mathrm{~kg}$ olarak tespit edilmiştir.

\section{Araştırma Düzeni ve Verilerin Toplanması}

$\mathrm{Bu}$ araştırmada kardiyovasküler hastalık riski, katılımcıların bel çevresi ve bel kalça oranı belirlenerek değerlendirilmiş ve kardiyovasküler hastalık riski katılımcıların cinsiyetlerine göre ayrı ayrı incelenmiştir. Kardiyovasküler hastalık riskinin değerlendirilmesinde bel çevresi ve bel kalça oranının kullanılması, ilgili literatürde daha önce yapılan birçok araştırmada başvurulan yaygın bir yöntemdir (Shen 2006; Klein 2007; ACSM 2013; Yılmaz \& Boylu 2016). Çeşitli araştırma sonuçlarına göre, bel çevresi ya da bel kalça oranı artıkça kardiyovasküler hastalık riskinin de artı̆̆ bildirilmektedir (Shen 2006; Klein 2007; Meseri \& Ünal 2009).

Bu çalışmada bel çevresi, katılımcı ayakta iken son kaburga ile krista illiak orta hattına denk gelen umblikus hizasından geçen çevre olarak değerlendirilmiş ve santimetre olarak esnek olmayan mezura ile ölçülmüsşür. Bu değere göre, katılımcılarda kardiyovasküler hastalık riski olarak abdominal obezite değerlendirilmiştir. Bel çevresi, erkeklerde $94-101 \mathrm{~cm}$, kadınlarda 80$87 \mathrm{~cm}$ arasında ise "artmış kardiyovasküler hastalık riski"; erkeklerde $\geq 102 \mathrm{~cm}$, kadınlarda $\geq 88$ cm ise "yüksek kardiyovasküler hastalık riski" olarak kabul edilmiştir (Shen 2006; Klein 2007; ACSM 2013).

Kalça çevresi ise, katılımcının her iki trokanter major femoris hizasına denk gelen kalça kaslarının maksimal çıkıntı yaptığı seviyeden santimetre olarak esnek olmayan mezura ile ölçülmüştür (ACSM 2013). Daha sonra her katılımcı için bel kalça oranı hesaplanarak, bu değer; erkeklerde $\geq 0,90$ ve kadınlarda $\geq 0,85$ ise "kardiyovasküler hastalık riskini artırıcı bir etken" olarak kabul edilmiştir (WHO 1999).

Bununla birlikte bu araştırmada katılımcılara ilişkin fiziksel aktivite düzeyini değerlendirmek amacıyla uluslararası geçerlilik ve güvenirlik çalışmaları Craig ve arkadaşları (2003) tarafından yapılan ve ülkemizdeki geçerlilik ve güvenirlik çalışmaları Öztürk (2005) tarafından gerçekleştirilen "fiziksel aktivite değerlendirme anketi kısa formu" kullanılmıştır. Bu anket yedi soru ve iki sayfadan oluşmaktadır. Ankette bütün aktivitelerin değerlendirilmesinde her bir aktivitenin tek seferde en az 10 dakika yapılıyor olması ölçütü kullanılmıştır. Katılımcıların demografik bilgilerinin de istendiği ilave formun yanı sıra, fiziksel aktivite değerlendirme anketi ile katılımcıların son bir hafta içerisinde yürüme ve oturma süreleri, orta düzeyli fiziksel aktivite süreleri ve şiddetli fiziksel aktivite süreleri dakika olarak sorgulanmıştır. Orta düzeyli fiziksel aktiviteler; hafif yük taşıma, normal hızda bisiklet çevirme, halk oyunları, dans, bowling veya çiftler tenis oyunu gibi orta şiddette aktiviteleri kapsarken, şiddetli fiziksel aktiviteler ise; ağır kaldırma, kazma, aerobik, basketbol, futbol veya hızlı bisiklet çevirme gibi şiddetli aktiviteleri kapsamaktadır.

Katılımcılara ilişkin yürüme, orta düzeyli fiziksel aktivite ve şiddetli fiziksel aktivite süreleri aşağıdaki eşitlikler ile bazal metabolik hıza karşılık gelen MET (dinlenmedeki oksijen tüketiminin katları) değerine çevrilerek toplam fiziksel aktivite skoru MET-dakika/hafta olarak hesaplanmiştır (Craig 2003). Buna göre, “yürüme skoru = 3,3 * yürüme süresi * yürüme günü”, "orta şiddetli aktivite skoru $=4,0 *$ orta şiddetli aktivite süresi $*$ orta şiddetli aktivite günü" ve 
"şiddetli aktivite skoru $=8,0 *$ şiddetli aktivite süresi $*$ şiddetli aktivite günü" şeklinde METdakika/hafta olarak hesaplanırken, toplam fiziksel aktivite skoru; yürüme, orta şiddetli aktivite ve şiddetli aktivite skorlarının toplamı olarak hesaplanmıştır. Daha sonra "toplam fiziksel aktivite skoruna" göre katılımcıların fiziksel aktivite düzeyleri; "fiziksel olarak aktif olmayan (<600 MET-dakika/hafta)", "fiziksel aktivite düzeyi düşük olan (600-3000 MET-dakika/hafta)" ve "fiziksel aktivite düzeyi yeterli olan (>3000 MET-dakika/hafta)" şeklinde sinıflandırılmıştır (Craig 2003; Öztürk 2005).

\section{Verilerin Analizi}

Araştırmada tüm değişkenlere ilişkin sayısal verilerde aritmetik ortalama $(\bar{X})$ ve standart sapma (SS) değerleri, nitelik verilerde ise frekans (n) ve yüzde (\%) dağılımları hesaplanmıştır. Araştırma grubundaki bireylerin cinsiyetlerine göre ve kardiyovasküler hastalık riski durumlarına göre fiziksel aktivite düzeyleri Ki-kare Testi ile analiz edilmiştir. İstatistiksel analizler SPSS paket programında yapılmış ve uygulanan tüm istatistiksel işlemlerde $\alpha=0,05$ yanılma düzeyi dikkate alınmıştır.

\section{Bulgular}

Tıp Fakültesi Hastanesi masa başı çalışanlarında kardiyovasküler hastalık riski ve fiziksel aktivite düzeyinin incelenmesi amacıyla yapılan bu çalışmaya 128'i erkek, 273’ü ise kadın olmak üzere toplam 401 kişi gönüllü olarak katılmıştır. Katılımcıların cinsiyetlerine göre yaş, mesleki deneyim süresi, vücut ağırlığı, boy uzunluğu, MET cinsinden toplam fiziksel aktivite skorları, bel çevresi ve bel kalça oranı gibi bazı tanımlayıcı özellikleri Tablo 1'de verilmiştir.

Tablo 1. Katılımcıların Cinsiyete Göre Bazı Tanımlayıcı Özellikleri

\begin{tabular}{lccc}
\hline & $\begin{array}{c}\text { Erkek (n=128) } \\
\bar{X} \pm \text { SS }\end{array}$ & $\begin{array}{c}\text { Kadın (n=273) } \\
\bar{X} \pm \text { SS }\end{array}$ & $\begin{array}{c}\text { Toplam (n=401) } \\
\bar{X} \pm \text { SS }\end{array}$ \\
\hline Yaş (yıl) & $36,43 \pm 7,73$ & $33,03 \pm 6,12$ & $34,12 \pm 6,86$ \\
Mesleki Deneyim Süresi (yıl) & $10,11 \pm 6,96$ & $9,40 \pm 6,05$ & $9,63 \pm 6,36$ \\
Vücut Ă̆ırı̆̆ğ (kg) & $80,37 \pm 10,66$ & $62,83 \pm 10,48$ & $68,43 \pm 13,34$ \\
Boy Uzunluğu (cm) & $174,78 \pm 6,35$ & $162,37 \pm 5,47$ & $166,34 \pm 8,17$ \\
MET (dakika/hafta) & $1257,30 \pm 1107,35$ & $1009,10 \pm 1345,30$ & $1088,33 \pm 1278,05$ \\
Bel Çevresi (cm) & $86,59 \pm 13,93$ & $77,45 \pm 11,58$ & $80,37 \pm 13,08$ \\
Bel Kalça Oranı & $0,86 \pm 0,084$ & $0,80 \pm 0,083$ & $0,82 \pm 0,089$ \\
\hline
\end{tabular}

Tablo 1'de görüldüğü gibi, toplam fiziksel aktivite skoru ya da haftalık enerji tüketimi ortalamasına göre erkek katılımcıların fiziksel aktivite düzeyleri kadınlara göre daha yüksek olmakla birlikte, gerek erkek gerekse kadın masa başı çalışanların düşük fiziksel aktivite düzeyine sahip oldukları belirlenmiştir (düşük düzeyde fiziksel aktivite; 600-3000 MET-dakika/hafta). Bununla birlikte, katılımcılarda kardiyovasküler hastalık riski olarak değerlendirilen bel çevresi ve bel kalça oranı genel ortalama değerleri dikkate alındığında ise, bu örneklemi oluşturan gerek erkek gerekse kadın masa başı çalışanların artmış ya da yüksek kardiyovasküler hastalık riski taşımadığı söylenebilir (Tablo 1). Katılımcılara ilişkin yaş ortalamasının tablo 1'de görüldüğü gibi nispeten yüksek olmaması (erkeklerde 36,43 \pm 7,73 y1l, kadınlarda 33,03 \pm 6,12 y1l) bunda etken olabileceği gibi, farklı birçok değişkenin de (morfolojik özellikler, beslenme alışkanlığ 1 gibi) etkisi olabilir. 
Katılımcıların cinsiyete göre fiziksel aktivite düzeyleri Tablo 2'de verilmiştir.

Tablo 2. Katılımcıların Cinsiyete Göre Fiziksel Aktivite Düzeyleri

\begin{tabular}{lcccccc}
\hline & \multicolumn{2}{c}{ Erkek $\mathbf{( n = 1 2 8 )}$} & \multicolumn{2}{c}{ Kadın $(\mathbf{n = 2 7 3 )}$} & \multicolumn{2}{c}{ Toplam $(\mathbf{n = 4 0 1 )}$} \\
\cline { 2 - 7 } Fiziksel Aktivite Düzeyi & $\mathbf{N}$ & $\mathbf{\%}$ & $\mathbf{n}$ & $\mathbf{\%}$ & $\mathbf{n}$ & $\mathbf{\%}$ \\
\hline Aktif Olmayan & 42 & 32,8 & 146 & 53,5 & 188 & 46,9 \\
Düşük & 78 & 60,9 & 109 & 39,9 & 187 & 46,6 \\
Yeterli & 8 & 6,3 & 18 & 6,6 & 26 & 6,5 \\
Toplam & 128 & 100,0 & 273 & 100,0 & 401 & 100,0 \\
\hline
\end{tabular}

$\left(\chi^{2}=16.204, p=0.000\right)$

Tablo 2 incelendiğinde, katılımcıların cinsiyetten bağımsız olarak toplamda \%46,9'unun fiziksel olarak aktif olmadığı, \%46,6'sının düşük fiziksel aktivite düzeyine sahip olduğu ve sadece $\% 6,5$ 'inin yeterli düzeyde fiziksel aktivite yaptığ 1 görülmektedir. Katılımcılara ilişkin fiziksel aktivite düzeyleri cinsiyet durumuna göre değerlendirildiğinde ise, erkek masa başı çalışanların \%32,8'i “aktif olmayan”, \%60,9'u “düşük” ve \%6,3’ünün “yeterli” fiziksel aktivite düzeyine sahip olduğu, bu oranların kadın masa başı çalışanlarda \%53,5 “aktif olmayan”, \%39,9 “düşük” ve \%6,6 "yeterli" şeklinde gerçekleştiği tespit edilmiştir. Bununla birlikte, katılımcıların cinsiyete göre fiziksel aktivite düzeylerinde anlamlı farklılık bulunmuştur $\left(\chi^{2}=16.204, \mathrm{p}=0.000\right)$. Erkek masa başı çalışanlarda fiziksel aktivite düzeyinin kadın çalışanlara göre anlamlı ölçüde yüksek olduğu belirlenmiştir $(\mathrm{p}<0.05)$. Ancak erkek ve kadın masa başı çalışanlardaki fiziksel aktivite düzeyi farklılığının tablo 2'den de anlaşılacağı gibi, aktif olmayan ve düşük aktivite düzeylerindeki değişkenlikten kaynaklandığı görülebilir. Nitekim, örneklemi oluşturan masa başı çalışanların sadece \%6,5'i yeterli aktivite düzeyine sahiptir. Tablo 2'de de görüldüğü gibi yeterli düzeyde fiziksel aktivite sergileyen kadın çalışanların oranı \%6,6, erkek çalışanların oranı ise sadece \%6,3'dür. Başka bir deyişle, bu çalışmada örneklemi oluşturan masa başı çalışanların \%93,5’i fiziksel olarak aktif olmayan ya da düşük fiziksel aktivite düzeyine sahip bireylerden oluşmaktadır.

Erkek masa başı çalışanların bel çevresi gruplarına göre fiziksel aktivite düzeyleri Tablo 3'de görülmektedir.

Tablo 3. Erkek Katılımcıların Bel Çevresi Gruplarına Göre Fiziksel Aktivite Düzeyleri

\begin{tabular}{|c|c|c|c|c|c|c|}
\hline \multirow[b]{2}{*}{ Fiziksel Aktivite Düzeyi } & \multicolumn{2}{|c|}{$\begin{array}{l}93 \mathrm{~cm} \text { ve altı } \\
(n=67)\end{array}$} & \multicolumn{2}{|c|}{$\begin{array}{c}94-101 \mathrm{~cm} \text { arasi } \\
(\mathrm{n}=34)\end{array}$} & \multicolumn{2}{|c|}{$\begin{array}{c}102 \text { cm ve üstü } \\
(n=27)\end{array}$} \\
\hline & $\mathbf{n}$ & $\%$ & $\mathbf{n}$ & $\%$ & $\mathbf{n}$ & $\%$ \\
\hline Aktif Olmayan & 21 & 31,3 & 10 & 29,4 & 11 & 40,7 \\
\hline Düşük & 42 & 62,7 & 22 & 64,7 & 14 & 51,9 \\
\hline Yeterli & 4 & 6,0 & 2 & 5,9 & 2 & 7,4 \\
\hline Toplam & 67 & 100,0 & 34 & 100,0 & 27 & 100,0 \\
\hline
\end{tabular}

$\left(\chi^{2}=5.438, p=0.272\right)$

Erkeklerde bel çevresi değeri $94 \mathrm{~cm}$ ile $101 \mathrm{~cm}$ arasında ise "artmış kardiyovasküler hastalık riski", $102 \mathrm{~cm}$ ve üstü değerlerde ise "yüksek kardiyovasküler hastalık riski" olarak değerlendirilmektedir (Shen 2006; Klein 2007; ACSM 2013). Bu çalışmada da erkek katılımcıların kardiyovasküler hastalık riski, diğer bir yöntemin yanı sıra (bel kalça oranı) bu sınıflandırma yöntemi kullanılarak incelenmiştir. Buna göre tablo 3'ten de anlaşılacağı gibi, toplam 128 erkek masa başı çalışanının \%52,3’ü $(n=67)$ bel çevresi kriterine göre artmış ya da yüksek kardiyovasküler hastalık riski taşımamaktadır. Diğer taraftan erkek katılımcıların \%26,6'sı (n=34) 
artmış kardiyovasküler hastalık riski taşırken, \%21,1 (n=27) yüksek kardiyovasküler hastalık riski taşımaktadır. Bununla birlikte tablo 3 'te de görüldüğ̈̈ gibi, erkek katılımcıların bel çevresi gruplarına ya da kardiyovasküler hastalık riski gruplarına göre fiziksel aktivite düzeylerinde anlamlı değişkenlik yoktur $\left(\chi^{2}=5.438, \mathrm{p}=0.272\right)$. Bu durum örneklemdeki erkek katılımcıların büyük oranda $(\% 93,7)$ düşük ya da aktif olmayan fiziksel aktivite düzeyi gruplarında yer alıyor olmasından ya da diğer bir deyişle fiziksel aktivite düzeylerinin oldukça yetersiz olmasından kaynaklı olabilir. Bir diğer olasılıkta, örneklemdeki erkek katılımcıların yarısından fazlası $(\% 52,3)$ artmış veya yüksek kardiyovasküler hastalık riski taşımamaktadır.

Kadın masa başı çalışanların bel çevresi gruplarına göre fiziksel aktivite düzeyleri Tablo 4'de sergilenmiştir.

Tablo 4. Kadın Katılımcıların Bel Çevresi Gruplarına Göre Fiziksel Aktivite Düzeyleri

\begin{tabular}{lcccccc}
\hline & \multicolumn{2}{c}{$\begin{array}{c}\mathbf{7 9} \mathbf{~ c m} \text { ve altı } \\
(\mathbf{n = 1 5 6 )}\end{array}$} & $\begin{array}{c}\mathbf{8 0 - 8 7} \mathbf{~ c m} \text { arası } \\
(\mathbf{n = 6 4 )}\end{array}$ & \multicolumn{2}{c}{$\begin{array}{c}\mathbf{8 8} \mathbf{~ c m} \text { ve üstü } \\
\text { (n=53) }\end{array}$} \\
\cline { 2 - 7 } Fiziksel Aktivite Düzeyi & $\mathbf{n}$ & $\mathbf{\%}$ & $\mathbf{n}$ & $\mathbf{\%}$ & $\mathbf{n}$ & $\mathbf{\%}$ \\
\hline Aktif Olmayan & 83 & 53,2 & 33 & 51,6 & 30 & 56,6 \\
Düşük & 64 & 41,0 & 27 & 42,2 & 18 & 34,0 \\
Yeterli & 9 & 5,8 & 4 & 6,2 & 5 & 9,4 \\
Toplam & 156 & 100,0 & 64 & 100,0 & 53 & 100,0 \\
\hline
\end{tabular}

$\left(\chi^{2}=1.565, \mathbf{p}=0.815\right)$

Kadınlarda bel çevresi değeri $80 \mathrm{~cm}$ ile $87 \mathrm{~cm}$ arasında ise "artmış kardiyovasküler hastalık riski", $88 \mathrm{~cm}$ ve üstü değerlerde ise "yüksek kardiyovasküler hastalık riski” olarak değerlendirilmektedir (Shen 2006; Klein 2007; ACSM 2013). Bu araştırmada da kadın katılımcıların kardiyovasküler hastalık riski, bel kalça oranının yanı sıra, bu sınıflandırma yöntemi kullanılarak incelenmiştir. Tablo 4'de görüldüğü gibi, örnekleme dahil olan toplam 273 kadın masa başı çalışanının \%57,2'si (n=156) bel çevresi kriterine göre artmış ya da yüksek kardiyovasküler hastalık riski taşımamaktadır. Bununla birlikte, kadın katılımcıların \%23,4'ü $(n=64)$ artmış kardiyovasküler hastalık riski taşırken, sadece \%19,4’ü $(\mathrm{n}=53)$ yüksek kardiyovasküler hastalık riski taşımaktadır. Ayrıca tablo 4'te de görüldüğü gibi, kadın katılımcıların bel çevresi gruplarına ya da kardiyovasküler hastalık riski gruplarına göre fiziksel aktivite düzeylerinde anlamlı değişkenlik yoktur $\left(\chi^{2}=1.565, \mathrm{p}=0.815\right)$. Erkek katılımcılarda olduğu gibi, kadın katılımcıların da büyük oranda (\% 93.4) düşük ya da aktif olmayan fiziksel aktivite düzeyi gruplarında yer alıyor olması ve kadın katılımcıların da yarısından fazlasının $(\% 57,2)$ artmış veya yüksek kardiyovasküler hastalık riski taşımaması, bel çevresi gruplarına göre fiziksel aktivite düzeylerinde anlamlı değişkenlik gözlenmemiş olamasını açıklayabilir.

Tablo 5'te erkek masa başı çalışanların bel kalça oranı gruplarına göre fiziksel aktivite düzeyleri verilmiştir.

Tablo 5. Erkek Katılımcıların Bel Kalça Oranı Gruplarına Göre Fiziksel Aktivite Düzeyleri

\begin{tabular}{lcccc}
\hline & \multicolumn{2}{c}{$\begin{array}{c}\mathbf{0 . 8 9} \text { ve altı } \\
(\mathbf{n = 7 4 )}\end{array}$} & \multicolumn{2}{c}{$\begin{array}{c}\text { 0.90 ve üstü } \\
\text { (n=54) }\end{array}$} \\
\cline { 2 - 5 } Fiziksel Aktivite Düzeyi & $\mathbf{n}$ & $\mathbf{\%}$ & $\mathbf{n}$ & \% \\
\hline Aktif Olmayan & 26 & 35,1 & 16 & 29,6 \\
Düşük & 44 & 59,5 & 34 & 63,0 \\
Yeterli & 4 & 5,4 & 4 & 7,4 \\
Toplam & 74 & 100.0 & 54 & 100.0 \\
\hline
\end{tabular}

$\left(\chi^{2}=0.551, p=0.759\right)$ 
Erkeklerde bel kalça oranı 0,90 ve üstü değerlerde ise "kardiyovasküler hastalık riskini artırıcı bir etken" olarak kabul edilmektedir (WHO 1999). Bu çalışmada katılımcıların kardiyovasküler hastalık riski ayrıca bu sınıflandırma yöntemi ile de incelenmiştir. Tablo 5'te görüldüğü gibi, örnekleme dahil olan toplam 128 erkek masa başı çalışanının \%57,8'i (n=74) bel kalça oranı kriterine göre kardiyovasküler hastalık riskini artırıcı bir etkene maruz değildir. Bununla birlikte, erkek katılımcıların \%42,2'si (n=54) ise kardiyovasküler hastalık riskini artırıcı bir etkene sahiptir. Diğer taraftan, tablo 5'te de görüldüğ̈̈ gibi, erkek katılımcıların bel kalça oranı gruplarına göre fiziksel aktivite düzeylerinde anlamlı farklılık yoktur $\left(\chi^{2}=0.551, \mathrm{p}=0.759\right)$. Başka bir deyişle, erkek katılımcılarda fiziksel aktivite düzeyi, kardiyovasküler hastalık riskini artırıcı bir etken olarak kabul edilen bel kalça oranı gruplarına göre değişkenlik sergilememektedir ( $>0.05)$. Erkek katılımcıların neredeyse tamamına yakınının $(\% 93,7)$ düşük ve aktif olmayan fiziksel aktivite düzeyi gruplarında yer alıyor olması ve yarısından fazlasının $(\% 57,8)$ kardiyovasküler hastalık riskini artırıcı bir etkene maruz olmaması, bel kalça oranı gruplarına göre fiziksel aktivite düzeylerinde istatistiksel olarak anlamlı değişkenlik belirlenmemiş olmasını açıklayabilir.

Tablo 6'da kadın masa başı çalışanların bel kalça oranı gruplarına göre fiziksel aktivite düzeyleri görülmektedir.

Tablo 6. Kadın Katılımcıların Bel Kalça Oranı Gruplarına Göre Fiziksel Aktivite Düzeyleri

\begin{tabular}{lcccc}
\hline & \multicolumn{2}{c}{$\begin{array}{c}\mathbf{0 . 8 4} \text { ve altı } \\
(\mathbf{n = 1 8 7 )}\end{array}$} & \multicolumn{2}{c}{$\begin{array}{c}\mathbf{0 . 8 5} \text { ve üstü } \\
\text { (n=86) }\end{array}$} \\
\cline { 2 - 5 } Fiziksel Aktivite Düzeyi & $\mathbf{n}$ & $\mathbf{\%}$ & $\mathbf{n}$ & \% \\
\hline Aktif Olmayan & 101 & 54.0 & 45 & 52.4 \\
Düşük & 75 & 40.1 & 34 & 39.5 \\
Yeterli & 11 & 5,9 & 7 & 8,1 \\
Toplam & 187 & 100,0 & 86 & 100,0 \\
\hline
\end{tabular}

$\left(\chi^{2}=0.491, p=0.782\right)$

Kadınlarda bel kalça oranı 0,85 ve üstü değerlerde ise "kardiyovasküler hastalık riskini artırıcı bir etken" olarak değerlendirilmektedir (WHO 1999). Dolayısı ile Tablo 6' da görüldüğü gibi, örnekleme dahil olan toplam 273 kadın masa başı çalışanının \%68,5'i (n=187) bel kalça oranı kriterine göre kardiyovasküler hastalık riskini artırıcı bir etkene sahip değildir. Bununla birlikte, kadın katılımcıların sadece \%31,5'i (n=86) kardiyovasküler hastalık riskini artırıcı bir etkene sahiptir. Diğer taraftan, tablo 6'da görüldüğü gibi, kadın katılımcıların bel kalça oranı gruplarına göre fiziksel aktivite düzeylerinde anlaml1 farklılık yoktur $\left(\chi^{2}=0.491, \mathrm{p}=0.782\right)$. Bir başka deyişle, kadın katılımcılarda fiziksel aktivite düzeyi, kardiyovasküler hastalık riskini artırıcı bir etken olarak kabul edilen bel kalça oranı gruplarına göre değişkenlik sergilememektedir $(\mathrm{p}>0.05)$. Erkeklerde olduğu gibi, kadın katılımcıların da neredeyse tamamına yakını $(\% 93,4)$ düşük ve aktif olmayan fiziksel aktivite düzeyi gruplarında yer almaktadır. Bununla birlikte \%68,5'i kardiyovasküler hastalık riskini artırıcı bir etkene sahip değildir. Dolayısı ile bu durum, bel kalça oranı gruplarına göre fiziksel aktivite düzeylerinde istatistiksel olarak anlamlı değişkenlik olmamasını açıklayabilir.

\section{Tartışma ve Sonuç}

$\mathrm{Bu}$ araştırmada masa başı çalışanların kardiyovasküler hastalık riski ve fiziksel aktivite düzeyleri cinsiyete göre incelenmiştir. Akdeniz Üniversitesi Tıp Fakültesi Hastanesinde günlük sekiz saat mesai süresince görevini ofislerde masa başında çalışarak ve bilgisayar kullanarak gerçekleştiren toplam 454 çalışandan 401'i gönüllü olarak bu araştırmaya dahil olmuştur. Dolayısı ile 
bu çalışmadaki katılımcılar araştırma evreninin \%88,3'ünü temsil etmektedir. Araştırmaya kat1lan toplam 401 masa başı çalışanından 273'ü kadın, 128'i ise erkektir.

$\mathrm{Bu}$ çalışmada elde edilen toplam fiziksel aktivite skoru ya da haftalık enerji tüketimi değerlerinin genel ortalaması dikkate alındığında erkek masa başı çalışanların $(1257.30 \pm 1107.35$ MET-dakika/hafta) fiziksel aktivite düzeyinin kadınlara göre (1009.10 \pm 1345.30 MET-dakika/hafta) daha yüksek olduğu belirlenmiştir. Bununla birlikte örneklemin genelinden elde edilen fiziksel aktivite skorunun 1088.33 \pm 1278.05 MET-dakika/hafta olarak belirlenmesi, gerek erkek gerekse kadın masa başı çalışanların düşük fiziksel aktivite düzeyine sahip olduklarını göstermektedir (düşük düzeyde fiziksel aktivite; 600-3000 MET-dakika/hafta). Nitekim toplam fiziksel aktivite skorlarına göre katılımcıların fiziksel aktivite düzeyleri sınıflandırıldığında, cinsiyetten bağımsız olarak masa başı çalışanların \%93,5'inin aktif olmayan ya da düşük fiziksel aktivite düzeyi gruplarında yer aldığı ve sadece \%6,5’inin yeterli fiziksel aktivite düzeyine sahip olduğu tespit edilmiştir. Bu sonuçlar masa başı çalışanlarda fiziksel aktivite davranışlarının yetersiz olması nedeniyle kardiyovasküler hastalıklar açısından gelecekteki riske işaret etmektedir. Fiziksel aktivite düzeyi cinsiyete göre incelendiğinde ise, erkek katılımcıların \%93,7'si, kadın katılımcıların \%93,4'ü aktif olmayan ya da düşük fiziksel aktivite düzeyi gruplarına dahildir. Erkek ve kadın masa başı çalışanların sırasıyla sadece \%6,3’ü ve \%6,6'sı yeterli fiziksel aktivite düzeyine sahiplerdir. Bununla birlikte erkek masa başı çalışanlarda fiziksel aktivite düzeyinin kadın çalışanlara göre anlamlı ölçüde yüksek olduğu belirlenmiştir. Ancak fiziksel aktivite düzeyindeki cinsiyet farklılığının aktif olmayan ve düşük fiziksel aktivite düzeyi gruplarındaki değişkenlikten kaynaklandığı yukarıdaki sonuçlardan da anlaşılabilir. Oysaki yetersiz ve düşük düzeyde fiziksel aktivitenin her iki cinsiyet açısından da kardiyovasküler hastalığa bağlı ölümün bağımsız bir öngörücüsü olduğu bildirilmektedir (Yılmaz \& Boylu 2016). Diğer taraftan Amerikan Kalp Birligi kardiyovasküler sağlığın korunabilmesi için haftada 150 dakika orta şiddette, 75 dakika yüksek şiddette fiziksel aktivite önermektedir (Pearson 2013). Örneklemi oluşturan masa başı çalışanlarda fiziksel aktivite düzeyinin bu ölçüde yetersiz olması, ileride oluşabilecek kardiyovasküler hastalıkların gelişme riskini daha da artırabilir. Bunun önüne geçilebilmesi için yetkililer tarafından gerekli önlemlerin alınarak masa başı çalışanlarda önlenebilir bir risk faktörü olan fiziksel aktivite düzeyini artıracak imkânlar sağlanmalıdır. Dünya Sağlık Örgütüne göre, yaşam tarzında yeterli miktarda değişikliklerle birlikte tüm kardiyovasküler hastalık ölümlerinin dörtte üçünün önüne geçilebilir. Toplumda kardiyovasküler hastalıklar açısından yüksek riskli grupları tanımlamak ve gerekli önlemleri önceden almak maliyetin azaltılmasında etkili bir stratejidir (Balc1 2018).

Diğer taraftan gerek ülkemizde gerekse yabancı ülkelerde farklı popülasyonlarla yapılan birçok çalışmada, erkeklerin kadınlara göre daha yüksek fiziksel aktivite düzeyine sahip oldukları rapor edilmiştir (Genç 2002; Shibata 2007; Şanlı 2008; Fişne 2009; Vural et al. 2010). Bu çalışmada ve diğer çalışmalarda bölge, 1rk, kültürel değişkenlik ve mesleki farklılık gözetmeden erkeklerin kadınlara göre daha fazla fiziksel aktivite sergiliyor olması, cinsiyetler arası fiziksel değişkenlik veya toplumsal rollerdeki değişkenlik ile ilişkilendirilebilir.

Kardiyovasküler hastalık riskinin değerlendirilmesine yönelik önerilen yöntemler santral obezitenin belirlenmesidir (Meseri \& Ünal 2009). Bu araştırmada kardiyovasküler hastalık riski, katılımcıların bel çevresi ve bel kalça oranı belirlenerek değerlendirilmiştir. Kardiyovasküler hastalık riskinin öngörülmesinde bel çevresi ve bel kalça oranının kullanılması, ilgili literatürde daha önce yapılan birçok araştırmada başvurulan ve yaygın olarak kullanılan bir yöntemdir (Shen 2006; Klein 2007; ACSM 2013; Yılmaz \& Boylu 2016). Çeşitli araştırma sonuçlarına göre, bel çevresi ya da bel kalça oranı artıkça kardiyovasküler hastalık riskinin de arttığı bildirilmektedir (Shen 2006; Klein 2007; Meseri \& Ünal 2009). Yapılan bir araştırmada bel kalça 
oranının kalp hastalığı riskini vücut kütle indeksine göre daha iyi yansıttığı gösterilmiştir (Siavash 2008). Diğer bir araştırmada ise kardiyovasküler hastalık riski bakımından bel çevresinin koroner kalp hastalığı oluşturma ihtimalinin hipertansiyon ve sigara tüketiminden sonra üçüncü sırada olduğu ve bel çevresinin kardiyovasküler hastalık riskinin değerlendirilmesinde en iyi antropometrik yöntem olabileceği vurgulanmıştır. Bununla birlikte, on iki santimetrelik bel genişlemesinin koroner kalp hastalığı riskini \%34 oranında artırdığı rapor edilmiştir (Onat 2003).

$\mathrm{Bu}$ çalışmada elde edilen bel çevresi ve bel kalça oranı genel ortalama değerleri dikkate alındığında, örneklemi oluşturan gerek erkek gerekse kadın masa başı çalışanların büyük oranda artmış ya da yüksek kardiyovasküler hastalık riski taşımadığı söylenebilir (Tablo 1). Ancak bel çevresi ve bel kalça oranı değerlerine göre yapılan sınıflandırmalarda gözlenen frekans dağılımları dikkate alındığında ise risk durumları daha detaylı analiz edilebilmektedir. Buna göre erkek katılımcıların bel çevresi kriterine göre \%26,6'sının artmış, \%21,1'inin ise yüksek kardiyovasküler hastalık riski taşıdığı, diğer taraftan \%52,3’ünün artmış ya da yüksek kardiyovasküler hastalık riski taşımadığı belirlenmiştir. Bel kalça oranı kriterine göre ise erkek katılımcıların \%42,2'si kardiyovasküler hastalık riskini artırıcı bir etkene sahipken, \%57,8'i kardiyovasküler hastalık riskini artırıcı bir etkene maruz değildir. Kadın katılımcılarda ise bel çevresi kriterine göre katılımcıların \%23,4'ünün artmış, \%19,4'ünün ise yüksek kardiyovasküler hastalık riski taşıdığı, ancak \%57,2'sinin artmış ya da yüksek kardiyovasküler hastalık riski taşımadığı belirlenmiştir. Bel kalça oranı kriterine göre değerlendirildiğinde ise kadın katılımcıların \%31,5’inin kardiyovasküler hastalık riskini artırıcı bir etkene sahip olduğu, diğer taraftan \%68,5'inin ise kardiyovasküler hastalık riskini artırıcı bir etkene sahip olmadığı tespit edilmiştir. Literatürde bel çevresi ve bel kalça oranını kardiyovasküler hastalık riski olarak ele alan ve yaş ortalaması

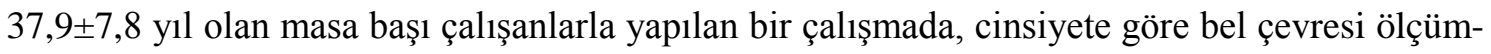
leri dikkate alındığında, kadınların üçte birinin riskli, dörtte birinin yüksek riskli, erkeklerin ise yarıya yakınının riskli ve üçte birinin yüksek riskli olduğu belirtilmektedir. Bel kalça oranına göre degerlendirildiginde ise, kadınların erkeklere göre daha büyük oranda risk taşıdığı bildirilmektedir (Yılmaz \& Boylu 2016). Bu araştırmada özellikle bel çevresine ilişkin olarak kaydedilen bulgularla Yılmaz ve Boylu'nun (2016) bildirdiği sonuçlar benzerlik göstermektedir. Ancak bu araştırmada bel kalça oranına ilişkin elde edilen bulgulardan, kadınların erkeklere göre daha düşük oranda riskli olduğu söylenebilir. Bu faklılık katılımcılara ilişkin yaş değişkeninden ileri gelebilir. Nitekim bu araştırmaya katılan erkek masa başı çalışanların yaş ortalaması 36,4 $\pm 7,7$ yıl iken, kadın katılımcılarda yaş ortalaması $33,0 \pm 6.1$ yıldır.

Bununla birlikte bu araştırmada gerek erkek gerekse kadın katılımcıların bel çevresi ve bel kalça oranı gruplarına ya da kardiyovasküler hastalık riski gruplarına göre fiziksel aktivite düzeylerinde anlamlı farklılık yoktur. Bir başka deyişle, katılımcılarda fiziksel aktivite düzeyi, kardiyovasküler hastalık riski olarak kabul edilen bel çevresi ya da bel kalça oranı gruplarına göre değişkenlik sergilememektedir. Bu durum örneklemdeki erkek ve kadın katılımcıların neredeyse tamamına yakınının (erkeklerin \%93,7'si, kadınların \%93,4'ü) zaten aktif olmayan ya da düşük fiziksel aktivite düzeyi gruplarında yer alıyor olmasından ya da diğer bir deyişle örneklemi oluşturan masa başı çalışanların fiziksel aktivite düzeyinin oldukça yetersiz olmasından kaynaklı olabilir. Örneklemi oluşturan bireylerde fiziksel aktivite düzeyi bu ölçüde düşük iken hem erkek hem de kadın katılımcıların yarısından fazlasının bel çevresi ve bel kalça oranı kriterlerine göre henüz kardiyovasküler hastalık riski taşımıyor olması, katılımcıların yaş ortalamasının halihazırda nispeten yüksek olmaması ile açıklanabilir (erkeklerde 36,4 yı1, kadınlarda 33,0 yıl). Katılımcıların morfolojik özellikleri ve beslenme alışkanlıkları da diğer açıklayıcı faktörler olabilir. Nitekim bu çalışmaya katılan katılımcılarda vücut kütle indeksi ortala- 
ma değeri $24,5 \mathrm{~kg} / \mathrm{m}^{2}$ 'dir ve bu, örneklemi oluşturan bireylerin büyük oranda boy uzunluğuna göre uygun vücut ağırlığına sahip olduklarını göstermektedir. Diğer taraftan bu çalışmada katılımcıların beslenme alışkanlıkları sorgulanmamıştır. Dolayısı ile gelecekte yapılacak benzer çalışmalarda bu konunun daha detaylı olarak sorgulanabilmesi adına katılımcıların farklı yöntemlerle vücut kompozisyonu değişkenleri ele alınmalı ve mutlaka beraberinde beslenme alışkanlıkları analiz edilmelidir.

Sonuç olarak, masa başı işi yapan bireylerin \%93,5'inin yetersiz fiziksel aktivite düzeyine sahip olduğu ve sadece \%6,5'inin fiziksel aktivite düzeyinin yeterli olduğu belirlenmiştir. Cinsiyete göre ise, erkek çalışanların \%93,7'si, kadın çalışanların \%93,4'ü yetersiz fiziksel aktivite düzeyine sahiptir. Erkek masa başı çalışanların sadece \%6,3'ü, kadınların ise sadece \%6,6'sı yeterli düzeyde fiziksel aktivite yapmaktadır. Erkek masa başı çalışanlarda fiziksel aktivite düzeyinin kadın çalışanlara göre anlamlı ölçüde yüksek olduğu belirlenmiştir. Ancak fiziksel aktivite düzeyindeki bu cinsiyet farklılığı, yeterli düzeyde fiziksel aktivite değişkenliğinden değil, aktif olmayan ve düşük fiziksel aktivite düzeyi gruplarındaki değişkenlikten kaynaklanmaktadır. Masa başı çalışanlarda fiziksel aktivite düzeyinin yetersiz olması, ileride oluşabilecek kardiyovasküler hastalıkların gelişme riskine işaret etmektedir. Diğer taraftan bel çevresi ve bel kalça oranı dağılımları dikkate alındığında, gerek erkek gerekse kadın katılımcıların yarısından fazlası artmış ya da yüksek kardiyovasküler hastalık riski taşımamaktadır. Bununla birlikte fiziksel aktivite düzeyi, kardiyovasküler hastalık riski olarak kabul edilen bel çevresi ya da bel kalça oranı gruplarına göre değişkenlik sergilememektedir. Bu durum örneklemi oluşturan bireylerin fiziksel aktivite düzeyinin oldukça yetersiz olmasından kaynaklı olabilir. Katılımcıların mevcut morfolojik özellikleri ve beslenme alışkanlıkları da olası diğer açıklayıcı faktörler olabilir. Gelecekte yapılacak araştırmalarda farklı vücut kompozisyonu değişkenleri de değerlendirilmeli ve beslenme alışkanlıkları analiz edilmelidir.

\section{Yazarın Notu}

Araştırmanın istatistiksel işlemlerinde görüş ve önerilerini aldığımız Dr. Zehra CERTEL'e teşekkürlerimizi iletiriz. 


\section{KAYNAKÇA}

American College of Sports Medicine (ACSM). (2013). ACSM's Guidelines for Exercise Testing and Prescription. Lippincott Williams \& Wilkins.

Balcı A. S., Kolaç N., Şahinkaya D., Yılmaz E. \& Nirgiz C. (2018). "Ofis Çalışanlarında Kardiyovasküler Hastalık Riski ve Bilgi Düzeyi”. Turkish Journal of Cardiovascular Nursing 9/18 (2018) 1-6.

Batty G. D. \& Lee I. M. (2004). "Physical Activity and Coronary Heart Disease. Fifty Years of Research Confirms Inverse Relationship”. British Medical Journal 328/7448 (2004) 1089-1090.

Craig C. L., Marshall A. L., Sjöström M., Bauman A. E., Booth M. L., Ainsworth B. E., Pratt M., Ekelund U., Yngve A., Sallis J. F. \& Oja P. (2003). "International Physical Activity Questionnaire: 12-Country Reliability and Validity”. Medicine and Science in Sports and Exercise 35/8 (2003) 1381-1395.

Fişne M. (2009). Fiziksel Aktivitelere Katılım Düzeyinin, Üniversite Öğrencilerinin Akademik Başarıları, İletişim Becerileri ve Yaşam Tatminleri Üzerine Etkilerinin İncelenmesi. Yüksek Lisans Tezi. Erciyes Üniversitesi, Sosyal Bilimler Enstitüsü. Kayseri 2009.

Genç M., Eğri M., Kurçer M. A., Kaya M., Pehlivan E., Karaoğlu L. \& Güneş G. (2002). "Malatya Kent Merkezindeki Banka Çalışanlarında Fiziksel Aktivite Sıklığı”. İnönü Üniversitesi Tıp Fakültesi Dergisi 9/4 (2002) 237-240.

Hamer M., Ingle L., Carroll S. \& Stamatakis E. (2012). "Physical Activity and Cardiovascular Mortality Risk: Possible Protective Mechanisms”. Medicine and Science in Sports and Exercise 44/1 (2012) 84-88.

Haskell W. L., Lee I. M., Pate R. R., Powell K. E., Blair S. N., Franklin B. A., Macera C. A., Heath G. W., Thompson P. D. \& Bauman A. (2007). "Physical Activity and Public Health: Updated Recommendation for Adults from The American College of Sports Medicine and The American Heart Association”. Medicine and Science in Sports and Exercise 39/8 (2007) 1423-1434.

Hua L. P., Brown C. A., Hains S. J., Godwin M. \& Parlow J. L. (2009). "Effects of Low-intensity Exercise Conditioning on Blood Pressure, Heart Rate, and Autonomic Modulation of Heart Rate in Men and Women with Hypertension”. Biological Research for Nursing 11/2 (2009) 129-143.

Klein S., Allison D. B., Heymsfield S. B., Kelley D. E., Leibel R. L., Nonas C. \& Kahn R. (2007). "Waist Circumference and Cardiometabolic Risk: A Consensus Statement from Shaping America's Health: Association for Weight Management and Obesity Prevention; NAASO, The Obesity Society; The American Society for Nutrition; and The American Diabetes Association”. Obesity 15/5 (2007) 10611067.

LaMonte M. J., Blair S. N. \& Church T. S. (2005). "Physical Activity and Diabetes Prevention”. Journal of Applied Physiology 99/3 (2005) 1205-1213.

Meseri R. \& Ünal B. (2009). "Kardiyovasküler Risk ve Diyabeti Belirlemede Şişmanlık Nasıl Ölçülmeli?”. TAF Preventive Medicine Bulletin 8/6 (2009) 507-514.

Onat A. (2003). “Türkiye’de Obezitenin Kardiyovasküler Hastalıklara Etkisi”. Türk Kardiyoloji Derneği Arşivi 31/5 (2003) 279-289.

Onat A. (2008). "Erişkinlerimizde Kalp Hastalıkları Prevalansı, Yeni Koroner Olaylar ve Kalpten Ölüm Sıklığı: Türk Erişkinlerinde Kalp Hastalıkları ve Risk Faktörleri Çalışması". TEKHARF çalışması Kaynak: <http://tekharf. org>.

Özer D. \& Baltacı G. (2008). İş Yerinde Fiziksel Aktivite. Klasmat Matbaacılık Ankara 2008.

Öztürk M. (2005). Üniversitede Eğitim-Öğretim Gören Öğrencilerde Uluslararası Fiziksel Aktivite Anketinin Geçerliliği ve Güvenirliği ve Fiziksel Aktivite Düzeylerinin Belirlenmesi. Yüksek Lisans Tezi. Hacettepe Üniversitesi, Sağlık Bilimleri Enstitüsü. Ankara 2005.

Pearson T. A., Palaniappan L. P., Artinian N. T., Carnethon M. R., Criqui M. H., Daniels S. R., Fonarow G. C., Fortmann S. P., Franklin B. A., Galloway J. M., Goff Jr. D. C., Heath G. W., Frank A. T. H., Kris-Etherton P. M., Labarthe D. R., Murabito J. M., Sacco R. L., Sasson C. \& Turner M. B. (2013). "American Heart Association Guide for Improving Cardiovascular Health at the Community Level, 2013 Update. A Scientific Statement for Public Health Practitioners, Healthcare Providers, and Health Policy Makers”. Circulation 127/16 (2013) 1730-1753.

Perry C. K. \& Bennett J. A. (2006). "Heart Disease Prevention in Women: Promoting Exercise”. Journal 
of The American Academy of Nurse Practitioners 18/12 (2006) 568-573.

Petersen S., Peto V., Rayner M., Leal J., Luengo-Fernández R. \& Gray A. (2008). European Cardiovascular Disease Statistics. British Heart Foundation. London 2008.

Shen W., Punyanitya M., Chen J., Gallagher D., Albu J., Pi Sunyer X., Lewis C. E., Grunfeld C., Heshka S. \& Heymsfield S. B. (2006). "Waist Circumference Correlates with Metabolic Syndrome Indicators Better Than Percentage Fat”. Obesity 14/4 (2006) 727-736.

Shibata A., Oka K., Nakamura Y. \& Muraoka I. (2007). "Recommended Level of Physical Activity and Health-Related Quality of Life among Japanese Adults”. Health and Quality of Life Outcomes 5/1 (2007) 64.

Siavash M., Sadeghi M., Salarifar F., Amini M. \& Shojaee-Moradie F. (2008). "Comparison of Body Mass Index and Waist/Height Ratio in Predicting Definite Coronary Artery Disease". Annals of Nutrition and Metabolism 53/3-4 (2008) 162-166.

Şanlı E. (2008). Öğretmenlerde Fiziksel Aktivite Düzeyi-Yaş, Cinsiyet ve Beden Kütle İndeksi İlişkisi. Yüksek Lisans Tezi. Gazi Üniversitesi. Ankara 2008.

Tsai J. C., Yang H. Y., Wang W. H., Hsieh M. H., Chen P. T., Kao C. C., Kao P. F., Wang C. H. \& Chan P. (2004). "The Beneficial Effect of Regular Endurance Exercise Training on Blood Pressure and Quality of Life in Patients with Hypertension”. Clinical and Experimental Hypertension 26/3 (2004) 255-265.

Vural Ö., Eler S. \& Güzel N. A. (2010). "Masa Başı Çalışanlarda Fiziksel Aktivite Düzeyi ve Yaşam Kalitesi İlişkisi”. Spormetre Beden Eğitimi ve Spor Bilimleri Dergisi 8/2 (2010) 69-75.

World Health Organization (WHO). (1999). Definition, Diagnosis and Classification of Diabetes Mellitus and Its Complications: Report of a WHO Consultation. Part 1, Diagnosis and Classification of Diabetes Mellitus (No. WHO/NCD/NCS/99.2). Geneva 1999.

Yılmaz M. \& Boylu M. (2016). "Masa Bası Çalışanlarda Kardiyovasküler Hastalık Risk Faktörleri Bilgi Düzeyleri ve Davranış Durumları". Koç Üniversitesi Hemşirelikte Eğitim ve Araştırma Dergisi 13/1 (2016) 27-34. 